\title{
O MAL-ESTAR DE ISAÍAS: A CRISE DO ROMANCE EM LIMA BARRETO
}

\author{
Carmem Lúcia Negreiros de FIGUEIREDO \\ Universidade do Estado do Rio de Janeiro \\ carmemluci@uol.com.br
}

Resumo: O artigo analisa o romance Recordações do escrivão Isaías Caminha (1907), de Lima Barreto (1881-1922), que anuncia a crise na capacidade de narrar, a partir da suspeita sobre a linguagem, com temporalidade complexa e questionamento da noção de subjetividade. $\mathrm{O}$ romance apresenta profunda crítica à ideia da essência lógica e racional de sujeito e de uma escrita capaz de transcrevê-la.

Palavras-chave: Lima Barreto. Romance. Crise.

Abstract: The article analyzes the novel Recordações do escrivão Isaías Caminha, written by Lima Barreto (1881-1920), which announces the crisis in the ability to narrate by means of suspicion about language, with complex temporality and the questioning of the notion of subjectivity. The novel presents a profound criticism to the idea of the logical and rational essence of subject and of writing as incapable of transcribing it.

Keywords: Lima Barreto. Novel. Crisis.

Lima Barreto (1881-1922) é um escritor cujas obras contêm várias camadas e, logo à superfície, seus leitores identificam as críticas a aspectos sociais e culturais, mas as demais camadas exigem maior repertório - e interesse - para reconhecer a inovação da linguagem, a crítica ao gênero literário em que são expressas questões filosóficas e reflexões acerca do papel do intelectual e da literatura. O processo de produção do escritor também envolve várias etapas, prazos, pesquisas e reescrita, sendo diverso da imagem de desleixo e rapidez a ele associada.

Ao contrário do que se diz, o escritor não dirige sua obra à população mais humilde, mas retira dela seus personagens, a fim de indicar a seus interlocutores, os intelectuais como ele, o efeito que têm sobre o destino e os sonhos a palavra escrita e o texto literário. Suas obras movimentam-se entre a adoção de técnicas que enfatizam a repetição, a redundância e os ganchos, próprios do texto de comunicação mais acessível, e reflexões e técnicas mais apuradas, que permitem questionar o padrão estético do texto, suas categorias principais e os grandes temas postos em debate pelo romance, na tradição literária.

\begin{tabular}{|l|l|l|l|l|}
\hline Pensares em Revista & São Gonçalo, RJ & n. 1 & 35-50 & jul.-dez. 2012 \\
\hline
\end{tabular}


Entre os temas preferidos do escritor, encontram-se os ligados à atuação intelectual, ao papel da leitura e do conhecimento, à escolha da memória para construir as narrativas, com estratégias de discurso autobiográfico. Esses temas funcionam como uma atração para o leitor envolver-se com a narrativa e manter vivo o fascínio pelo contar uma história. Em seguida, a obra amplia o significado esperado pelos leitores para os temas desenvolvidos.

Considerando que, em nossos dias, há um certo fascínio por relatos biográficos, memórias diversas e autobiografias, que tipo de lição podemos extrair de obras de Lima Barreto que, escritas nas primeiras décadas do século $\mathrm{XX}$, tratavam de relatos memorialísticos inseridos nos romances?

Vamos tomar como exemplo o seu romance de estreia, Recordações do escrivão Isaías Caminha, publicado em 1907, cujo título anuncia o percurso linear, por meio do relato autobiográfico do protagonista, desde sua chegada quando jovem na cidade do Rio de Janeiro até sua promoção a redator de um importante jornal e, depois, a político. $\mathrm{O}$ leitor incomoda-se diante de um final que não traz um apaziguamento e uma conclusão a essa trajetória do narrador. Ficamos sabendo no prefácio a última informação sobre a vida do protagonista, cuja contínua insatisfação e inquietude não permitem a resposta clara: foi bem-sucedido? Foi feliz?

Algumas questões perpassam a obra ficcional do escritor Lima Barreto, leitor de Nietzsche e muito atualizado com as reflexões filosóficas e literárias das primeiras décadas do século XX. Se a vida é fluxo e o eu é continuamente outro, qual escrita poderia fixá-lo, narrá-lo com precisão? A escrita memorialista é capaz de resgatar o vivido ou pode apenas reinventá-lo? Como narrar questionando a escrita sem deixar de contar uma boa história? Esses questionamentos envolvem a produção do romance de estreia do escritor carioca, cujo título é repleto de ecos da tradição literária: o termo 'memórias' é recorrente no nome de obras de ficção na literatura brasileira; 'escrivão' e 'Caminha' também são expressões que demonstram o diálogo com a tradição cultural e literária.

O foco do romance está no desejo do protagonista de narrar sua "luta íntima", que contamina de lirismo o aspecto épico do romance, tornando o espaço predominantemente imaginário e o tempo carregado de impressões e sensações com base na vivência do protagonista. A narrativa privilegia o tempo subjetivo e os acontecimentos narrados não

\begin{tabular}{|l|l|l|l|l|}
\hline Pensares em Revista & São Gonçalo, RJ & n. 1 & 35-50 & jul.-dez. 2012 \\
\hline
\end{tabular}


seguem plenamente um roteiro lógico e linear, mas movimentam-se entre lacunas, recuos, num entrecruzamento de temporalidades. É um romance que expõe os limites e impasses do gênero e transforma o narrar num processo próximo à montagem.

No prefácio, há uma superposição de discursos: os do autor, os do personagem narrador quando jovem e os do narrador quando adulto. A memória é o fio condutor que liga os estados emocionais narrados, mais valorizados que os acontecimentos. Se um prefácio "consolida a obra e a explica", como afirma Lima Barreto (1990), o de seu romance apresenta três tempos diversos, mas coerentes, ao que se verá no desenvolvimento da obra.

O primeiro tempo corresponde ao presente da publicação da segunda edição do romance - 1916 -, quando o autor comenta a recepção crítica aos primeiros capítulos surgidos na revista Floreal, que então ele dirigia, e, ainda, informa que já transcorreram dez anos, tanto da primeira publicação quanto da escrita dos manuscritos por Isaías Caminha, recurso que permite narrar os acontecimentos na vida do protagonista depois do ponto-final do romance.

O prefácio guarda, ainda, outro prefácio, o do pretenso autor das Recordações, transcrito por Lima Barreto. Nele, aparece a justificativa para a escrita das memórias, que data de 1905 e marca um segundo tempo. O terceiro tempo, ainda no prefácio, trata do passado do escrivão Isaías, retomado por imagens sínteses, a partir de reflexões, de sua trajetória anterior a 1905.

Um prefácio composto de fragmentos de escritas - de autor e personagem narrador - com tempos diversos anuncia o movimento do livro, a se constituir como uma espécie de montagem. Entre esses tempos, ficam as imagens marcantes dos estados psicológicos do protagonista, feitas de névoa, sinais místicos e com a imprecisão do claro-escuro, como frágil elo dessa narrativa que se organiza, pela montagem de fragmentos de memória, diante do leitor. Nesse processo, o protagonista raramente vislumbra o sol a pino, tampouco um céu fartamente iluminado; consegue, apenas, contemplar "uma nesga do céu", um "rasgão irregular".

No decorrer da obra, a memória do narrador intercala tempo e espaço, num constante vaivém entre passado e presente, a saber: a trajetória do narrador quando jovem; o presente do protagonista, permeado dessas lembranças que se tornam, aos poucos, as memórias ou recordações escritas; e o presente do autor, que apresenta o romance dez

\begin{tabular}{|l|l|l|l|l|}
\hline Pensares em Revista & São Gonçalo, RJ & n. 1 & 35-50 & jul.-dez. 2012 \\
\hline
\end{tabular}


anos após os acontecimentos nele relatados.

Somos levados, por uma narrativa em primeira pessoa, aos primeiros anos da juventude de Isaías, sua origem e formação diante do espetáculo de saber do pai e da simplicidade da mãe, praticamente analfabeta, até o capítulo IV, quando a narrativa intercala-se com longos períodos de reflexão do protagonista para expressar profundo desalento, angústia e solidão. A força dessas lembranças causa no presente do narrador muito sofrimento: “[...] depois de tantos anos de desgostos dessa ralação contínua pela minha luta íntima, precocemente velho pelo entrechoque de forças da minha imaginação desencontrada, desproporcionada e monstruosa [...]" (BARRETO, 1990, p. 46).

Envolvidos pelos acontecimentos da juventude de Isaías, recém-chegado ao Rio de Janeiro, para onde foi em busca do título de doutor, encontramos ao final do capítulo IV uma série de referências que permitem, simultaneamente, refletir sobre a finalidade do romance e seu diálogo com a tradição.

Primeiramente, temos a referência, num momento de angústia, abandono e solidão na cidade grande, do livro que fora seu guia de cabeceira: “[...] o Poder da vontade, com as suas biografias heroicas: Palissy, Watt, Franklin... Sorri satisfeito, orgulhoso; havia de fazer como eles" (BARRETO, 1990, p. 48). Ao voltar à leitura do jornal, o personagem lê enormes elogios ao padeiro Manuel Laje da Silva, apresentado como de conduta e reputação duvidosa: "Que acontecera? Recebera a bênção papal até a décima quinta geração. A notícia vinha cheia de gabos à sua atividade e à sua honestidade [...]" (BARRETO, 1990, p. 48). Uma interessante situação: a referência exemplar aos vencedores citados no livro, pelo mérito e talento, justaposta à notícia de jornal, que aplaude a reputação duvidosa.

Ainda no capítulo IV, outra referência nesse processo de montagem de pistas sobre o encaminhamento da narrativa, ainda em seu começo, leva a pensar no diálogo com $O$ vermelho e o negro (1830), de Stendhal (1783-1842). Após recordar-se de um momento de humilhação na juventude, o narrador afirma: "Hoje que sou um tanto letrado sei que Stendhal dissera que são esses momentos que fazem os Robespierres" (LIMA BARRETO, 1990, p. 48). A referência a Stendhal produz, em muitos leitores, a lembrança ou o diálogo de Lima Barreto com o escritor francês, como se o seu romance constituísse também uma narrativa semelhante à do romance europeu, mas repleta de problemas estéticos de realização, ao relatar a estória de um jovem em busca de ascensão,

\begin{tabular}{|l|l|l|l|l|}
\hline Pensares em Revista & São Gonçalo, RJ & n. 1 & 35-50 & jul.-dez. 2012 \\
\hline
\end{tabular}


prestígio e poder.

A crítica, muitas vezes, associou essa obra a outros romances importantes do século XIX, quer pela afinidade dos temas, quer pelas referências explícitas feitas pelo narrador a $O$ vermelho e o negro, de Stendhal, à obra A educação sentimental (1869), de Flaubert (1821-1880), ou ainda a Ilusões perdidas (1839) e Pai Goriot (1834), de Balzac (17991850). Entretanto, se, tal como em Balzac, percebemos em Lima Barreto a representação do cotidiano banal, feio e prático, por meio da mistura de estilos (Cf. AUERBACH, 1987), no caso do romance de Stendhal, o escritor dialoga com a crítica possível à relação existente entre pensar, sentir e fazer, sendo que a reflexão sobre a melhor maneira de agir não implica uma ação eficaz e coerente. Já de Flaubert, Lima Barreto assimila o interesse em projetar, na forma literária, os impasses, dilemas e fracassos do protagonista.

Considerado marco importante na representação da realidade na literatura ocidental, $O$ vermelho e o negro apresenta a crítica a certo padrão de associação entre pensar, sentir e fazer. Para Rancière (2010), a racionalização sobre o melhor ato não resulta na capacidade de tomar uma decisão racional e implementá-la. Nesse sentido, o fazer nada do plebeu Julien Sorel indica também, segundo o mesmo crítico, a nova distribuição do sensível, o compartilhamento da igualdade sensorial por uma classe a que antes era impossibilitado o direito ao ócio como devaneio; portanto, o "vazio do devaneio" torna-se possível, na ficção de Stendhal, “às almas das classes baixas” (RANCIÈRE, 2010, p. 87).

A divisão no cerne da ação associa-se à expressão da crise do modelo napoleônico, ou estratégico, de ação. Os ecos de Napoleão e o modelo de "grande homem" também chegaram a Isaías na sua fase de formação, por meio do discurso eloquente de seu pai. No entanto, ao jovem ficaram, apenas, "a entonação de voz, o gesto e o olhar" (BARRETO, 1990, p. 19).

Mas como dialogaria o romancista brasileiro com a poderosa imagem de $O$ vermelho e o negro?

Há, sem dúvida, pontos em franco diálogo. Primeiro, o desejo de investigar a complexidade dos motivos que movem os sujeitos; depois, a expressão de crise na linearidade da narrativa, mais precisamente no encadeamento de ações, e, ainda, a reflexão sobre o poder da leitura como propulsora de conhecimento e autoconhecimento, tema caro à produção romanesca de Lima Barreto.

Recordações do escrivão Isaías Caminha concentra-se no drama íntimo da

\begin{tabular}{|l|l|l|l|l|}
\hline Pensares em Revista & São Gonçalo, RJ & n. 1 & 35-50 & jul.-dez. 2012 \\
\hline
\end{tabular}


consciência do protagonista, por meio do velho recurso da onisciência do narrador, com o ponto de vista em primeira pessoa. Ainda que fartamente entremeado de narrações dos acontecimentos culturais e políticos que rodeiam o protagonista, é a representação da consciência do personagem, na sua vida interior, diante do confronto consigo mesmo e com a sociedade, o ponto forte dessas Recordações. O movimento da consciência recebe certa ordenação do narrar mesclado a associações imaginativas, no espaço entre as reminiscências e o presente da narrativa.

Escrevendo estas linhas, com que saudades me não recordo desse heroico anseio dos meus dezoito anos esmagados e pisados! Hoje... É noite. Descanso a pena. No interior da casa minha mulher acalenta meu filho único. A sua cantiga chega-me aos ouvidos cheia de um grande acento de resignação. Levanto-me e vou à varanda. A lua, no crescente, banha-me com meiguice, a mim e a minha humilde casa roceira. [...] Correm alguns instantes; ela cessa de cantar e o brilho do luar é empanado por uma nuvem passageira. Volto às minhas reminiscências: vejo o bonde, a gente que o enchia, os sofrimentos que me agitavam e a rua transitada [...] (BARRETO, 1990, p. 48).

A melancolia e a dor contaminam o narrador no presente, enquanto escreve suas memórias; melancolia e impotência de quem se arrasta, enquanto registra suas lembranças. O estado psicológico do narrador das memórias e do personagem quando jovem coadunam-se, portanto, e são visualizados na imagem frequente em todo o romance. "Nuvens plúmbeas já de todo tinham coberto a nesga do céu vista pela janela. Havia como que fuligem na atmosfera e a luz do sol tornara-se de um amarelo pardacento e fúnebre” (LIMA BARRETO, 1990, p. 52).

Dessa maneira, o mal-estar que acomete o jovem Isaías, após ser suspeito de roubo, intimado a comparecer a uma delegacia e ser chamado de "mulatinho" pelo delegado, também é o mesmo sentimento de Isaías narrador, adulto, relembrando aqueles dolorosos momentos para escrever suas memórias. "Despertei hoje cheio de um mal-estar que não sei de donde me veio. Nada ocorreu que o determinasse. [...] Penso - não sei por que que é este meu livro que me está fazendo mal [...]" (LIMA BARRETO, 1990, p. 56). Nesse sentido, a temporalidade escoa no romance, com o passado projetando-se sem cessar sobre o presente.

No entanto, há momentos de interessante alternância de estados emocionais do jovem Isaías, que são explicados pelo narrador mais maduro, posteriormente. Exemplo

\begin{tabular}{|l|l|l|l|l|}
\hline Pensares em Revista & São Gonçalo, RJ & n. 1 & 35-50 & jul.-dez. 2012 \\
\hline
\end{tabular}


disso é a cena em que, na delegacia, demonstra solidariedade à dor e desamparo de uma jovem lavadeira, protagonista de uma briga banal de vizinhas, moradoras, ambas, de uma casa de cômodos:

\begin{abstract}
As palavras saíam-lhe animadas, cheias de uma grande dor, bem distante da pueril querela que as provocara. Vinham das profundezas do seu ser, das longínquas partes que guardam uma inconsciente memória do passado, para manifestarem o desespero daquela vida, os sofrimentos milenares que a natureza lhe fazia sofrer e os homens conseguiram aumentar. Senti-me comunicado de sua imensa emoção; ela penetravame tão fundo que despertava nas minhas células já esquecidas a memória enfraquecida desses sofrimentos contínuos que me pareciam eternos; e achando-os por debaixo das noções livrescas, por debaixo da palavra articulada, no fundo de minha organização, espantei-me, aterreime, tive desesperos e cristalizei uma angústia que me andava esparsa (BARRETO, 1990, p. 54).
\end{abstract}

A solidariedade à dor alheia - que é também sua - acentua os traços de inquietação e angústia, marcas do personagem quando jovem e quando adulto, como narrador; solidariedade que expressa a percepção de um sentimento de humanidade, muito além da simples subjetividade. Novamente, a expressão de mal-estar acompanha-se do movimento da natureza: "A ela e ao meu abalo moral, juntavam-se a tonalidade amarelaça da tarde e o ambiente de forja para me dar um mal-estar nunca sentido" (BARRETO, 1990, p. 54).

A apresentação do estado emocional do jovem Isaías logo se acompanha da explicação do narrador, maduro, que usa a referência literária para esclarecer o movimento da consciência. A narrativa de um estado psíquico, antes da verbalização, a partir de impressões e reflexões, demonstra uma preocupação maior com aquilo que se é, ou que se pode tornar, do que com o relato de acontecimentos exteriores:

Por aí, houve em mim o que um autor russo chamou a convulsão da personalidade. Todo eu me agitei, todo eu me indignei. Senti num segundo todas as injustiças que vinha sofrendo; revoltei-me contra todos os sofrimentos que vinha suportando. Injustiças, sofrimentos, humilhações, misérias, juntaram-se dentro de mim, subiram à tona da minha consciência, passaram pelos meus olhos e então expectorei as sílabas: - Imbecil (BARRETO, 1990, p. 55).

Os incidentes constituem motivos para a introspecção e o autoconhecimento, incidentes que ocorrem num único dia, que começara com a observação do desfile de uma

\begin{tabular}{|l|l|l|l|l|}
\hline Pensares em Revista & São Gonçalo, RJ & n. 1 & 35-50 & jul.-dez. 2012 \\
\hline
\end{tabular}


fanfarra militar em que "os oficiais pareceram-me de um país e as praças de outro. Era como se fosse um batalhão de sipaios ou de atiradores senegaleses" (BARRETO, 1990, p. 38). Depois do desenrolar de uma série de decepções e injustiças, a culminância de reflexões sobre o contexto cultural mescladas a sentimentos íntimos vem na ironia: "As lágrimas correram-me e eu pensei comigo: A pátria!” (BARRETO, 1990, p. 55).

No romance, não é a ação, portanto, que predomina e todos os acontecimentos realizam-se no perscrutar das lembranças e dos pensamentos do protagonista. Os aspectos cronológicos, culturais e históricos constituem elos entre os dois momentos, o vivido e o narrado, e apenas reforçam a complexidade temporal da narrativa.

Do capítulo VII, quando inicia a trajetória de Isaías na imprensa, até o capítulo $\mathrm{XIV}$, o último do romance, as mesmas reflexões e estado psíquico do protagonista quando jovem e quando memorialista - permanecem, com um misto de angústia, impotência, desolação e, acima de tudo, solidão, mesmo depois de bem empregado como redator de importante jornal.

No último capítulo do romance, há sinais claros de ascensão social do protagonista: "Dois meses antes era simples contínuo, limpava mesas, ia a recados de todos; agora, poderosas autoridades queriam as minhas relações e a minha boa vontade" (BARRETO, 1990, p. 135). No entanto, há também índices de transformação interior: a capacidade de reagir com violência às ofensas e humilhações. Assim, diante da provocação de um colega jornalista, Isaías reage com violência e força: "Senti-me outro, muito mais forte, transtornado e desejoso de matar" (BARRETO, 1990, p. 136). Portanto, da convulsão interior e balbucio do jovem recém-chegado à capital, na delegacia, no capítulo VII, ao agora orgulhoso jornalista:

Encontrei o tal repórter na Rua Primeiro de Março e antes que ele fizesse o menor movimento atirei-me sobre o seu corpanzil, deitei-o por terra e dei-lhe com quanta força tinha. Na delegacia, a minha vontade era rir-me de satisfação, de orgulho, de ter sentido por fim que, no mundo, é preciso o emprego de violência, do murro, do soco, para impedir que os maus e os covardes não nos esmaguem de todo (BARRETO, 1990, p. 136).

Apesar do dinheiro, das pândegas, da sensação de domínio e controle, o reencontro com um cenário de interior - casas pobres, com quintais, em região rural - provoca no protagonista a reflexão de que não avançara, pessoalmente, em nada com relação a seus

\begin{tabular}{|l|l|l|l|l|}
\hline Pensares em Revista & São Gonçalo, RJ & n. 1 & 35-50 & jul.-dez. 2012 \\
\hline
\end{tabular}


sonhos. Na sua viagem do interior para a cidade, seu estado psíquico desmancha-se em apatia e dilacerações, numa angústia contínua do sujeito alquebrado diante das dificuldades externas.

Fomos servidos em velhos pratos azuis com uns desenhos chineses e as facas tinham ainda aquele cabo de chifre de outros tempos. À vista deles, dos pratos velhos e daquelas facas, lembrei-me muito da minha casa, e da minha infância. Que tinha eu feito? Que emprego dera à minha inteligência e à minha atividade? Essas perguntas angustiavamme. [...] Lembrava-me de que deixara toda a minha vida ao acaso e que não a pusera ao estudo e ao trabalho com a força de que era capaz. Sentia-me repelente, repelente de fraqueza, de falta de decisão e mais amolecido agora com o álcool e com os prazeres... Sentia-me parasita, adulando o diretor para obter dinheiro (BARRETO, 1990, p. 142-143).

$\mathrm{Na}$ avaliação de sua vida, restam ao personagem frustração e dor: "Sentia-me sempre desgostoso por não ter tirado de mim nada de grande, de forte e ter consentido em ser um vulgar assecla e apaniguado de um outro qualquer. [...] Por que o tinha sido? Um pouco devido aos outros e um pouco devido a mim" (BARRETO, 1990, p. 143).

O escrivão Isaías, ao escrever suas memórias, reconhece que não é mais tempo de ler nos astros o destino dos homens - "A nossa humanidade já não sabe ler nos astros os destinos e os acontecimentos" (BARRETO, 1990, p. 143) - embora, na sua juventude, tenha se guiado por sinais, como o movimento de aves no céu, que formavam um $\mathrm{V}$ indicando, na sua interpretação, um "vai”, estímulo para deixar o interior e tentar a vida na capital.

Quais são as consequências dessa perspectiva para o romance, para as memórias que Isaías escreve?

Há uma forte presença de elementos formais que alteram significativamente o princípio épico. Se, no romance do século XIX, a abordagem psicologizante é mediada pelo narrador (à exceção de Flaubert), recursos como o monólogo interior garantem, ainda, a distância épica.

Em Recordações do escrivão Isaías Caminha, a interiorização retira do tempo presente e real e da ação sua importância como princípio formal, o que expressa a crise do romance na tentativa de mostrar a diminuição da perspectiva, isto é, da distância crítica para representar o mundo e os sujeitos. O fluxo da vida psíquica absorve o mundo, que, por sua vez, traz as marcas do sujeito. O sujeito não tem mais a certeza da consciência

\begin{tabular}{|l|l|l|l|l|}
\hline Pensares em Revista & São Gonçalo, RJ & n. 1 & 35-50 & jul.-dez. 2012 \\
\hline
\end{tabular}


privilegiada, para, a partir dela, constituir uma realidade ou narrar uma estória. A voz gramatical - o eu do narrador - não revela distância, ou superioridade, e indica que ainda faz parte dos acontecimentos narrados, uma vez que as dores e inquietações são comuns ao narrador, adulto e amadurecido, e ao jovem, personagem das memórias. O discreto embate entre as vozes do autor, do eu narrador e do personagem é índice forte da consciência metaficcional sobre o narrar e da consciência da incompletude ou insuficiência de sentido para a existência.

Nesse aspecto, há o constante questionamento acerca da eficácia da linguagem para realizar tal comunicação, por meio do narrador Isaías: "Se me esforço por fazê-lo literário é para que ele possa ser lido, pois quero falar das minhas dores e dos meus sofrimentos ao espírito geral e no seu interesse, com a linguagem acessível a ele" (BARRETO, 1990, p. 56). Já entre o desejo, o pensamento e a linguagem, não há transparência e certeza, mas suspeita e insegurança quanto ao narrar, como questiona Isaías: "Quem sabe se ele me não vai saindo um puro falatório?" (BARRETO, 1990, p. 56). Boa parte dos fatos narrados diz respeito ao íntimo do protagonista; as humilhações, frustrações e perdas ainda estão no presente, na alma do narrador, o que elimina a visão perspectivística, estabelecendo a temporalidade uma duração, com a forte presença do passado no presente.

Se as imagens do mar são o índice do ápice de desespero do jovem Isaías - "Aos poucos ele hipnotizou-me, atraiu-me, parecia que me convidava a ir viver nele, a dissolver-me nas suas águas infinitas, sem vontade nem pensamentos" (BARRETO, 1990, p. 61) -, o movimento do rio e a melancolia do já amadurecido Isaías indicam a semelhança de estados de alma de narrador e protagonista.

\footnotetext{
Por que não estou satisfeito? Não sei. E quem o poderá saber! Há em nós tanta cousa misteriosa, tantos sentimentos cuja origem nos escapam, que me esforço em vão por explicar este meu atual estado d'alma. De uns tempos a esta parte, acontece-me isto amiudadas vezes. Tudo vai correndo normalmente; os dias com o mesmo enfado de sempre, e as noites serenas e plácidas; entretanto, esta ou aquela manhã, ergo-me e olho pela janela aberta, o rio que desliza lá embaixo, ensombrado de melancolia, cheio de lassidão, com maus desejos passando-me pela cabeça (BARRETO, 1990, p. 56).
}

Todos os elementos formais explicitados até aqui são próprios do romance do século XX, mas inserem-se no âmago do romance que se anuncia, pelo título, como uma

\begin{tabular}{|l|l|l|l|l|}
\hline Pensares em Revista & São Gonçalo, RJ & n. 1 & 35-50 & jul.-dez. 2012 \\
\hline
\end{tabular}


narrativa de perfil semelhante ao dos romances realistas do século XIX. No entanto, a expectativa anunciada não se cumpre.

Se a intenção do escrivão Isaías é produzir uma obra autobiográfica, espera-se, então, um aprofundamento do eu, com a finalidade de explicar as diferenças entre a subjetividade e o mundo, as causas da angústia que o dilacera pela não realização de seus sonhos. O sujeito buscaria, portanto, autoconhecimento e expressão pela exposição de si numa ordem narrativa e de uma perspectiva privilegiada: ninguém melhor do que o protagonista para responder às questões sobre sua identidade, sendo, por isso, capaz de demonstrar convicção e segurança na apresentação, e justificativa, dos fatos. Em outras palavras, estabeleceria a si mesmo como campo de observação e investigação. No entanto, as memórias de Isaías anunciam outras formas de falar de si.

Não se constitui, na obra, a perspectiva cartesiana de representação da subjetividade, numa escrita triunfante que teria como pressuposto a capacidade de selecionar critérios, estratégias e recursos persuasivos para projetar a si mesmo, de modo a levar ao receptor uma imagem de um sujeito capaz de compreender a natureza, as relações sociais e, principalmente, a si mesmo. Isaías Caminha não responde às perguntas sobre sua identidade, seu percurso de conhecimento e autoconhecimento; apenas formula perguntas e as projeta para o leitor.

Tampouco nele percebemos o sujeito com pretensão à verdade, num movimento de introspecção e autoexploração, isto é, uma proposta de conhecimento de si a partir da sensibilidade, na busca de transparência e completude na apreensão e registro de sentimentos e valores. Nem pela razão, tampouco pela sensibilidade, Isaías demonstra conhecimento pleno de si e dos motivos de suas dores.

O processo de construção do sujeito, no romance, não é fechado, unitário, concluso, uma vez que as vozes dos outros - as pressões, impressões, injunções vindas dos outros constituem e moldam o sujeito, num cruzamento de forças, ou seja, a identidade forma-se no meio desse cruzamento de forças e interesses. Tal ideia de subjetividade também sugere que não existe um espaço e forma privilegiados de representação das próprias vivências, mas a escrita está em processo, com os outros, tanto quanto o sujeito. Assim, as oscilações do sujeito e as turbulências da forma do romance (prefácio com tempos e vozes diversos que se projetam na narrativa) coadunam-se, de maneira coerente. A escrita não é somente o relato das experiências vitais, ela mesma se torna uma experiência.

\begin{tabular}{|l|l|l|l|l|}
\hline Pensares em Revista & São Gonçalo, RJ & n. 1 & 35-50 & jul.-dez. 2012 \\
\hline
\end{tabular}


As consequências (ou a escolha) desse processo aparecem na forma do romance, uma espécie de montagem e justaposição de vozes narrativas que se evidencia desde o prefácio, mas estende-se por toda a obra, tendo como ponto culminante o último capítulo. Nele, o autor intervém no discurso do personagem Isaías, como a quebrar o pacto ficcional, exatamente na explanação sobre os preconceitos acerca da capacidade intelectual de jovens pobres e mulatos, cujo exemplo é o protagonista.

[...] fiquei animado, como ainda estou, a contradizer tão malignas e infames opiniões, seja em que terreno for, com obras sentidas e pensadas, que imagino ter força para realizá-las, não pelo talento, que julgo não ser muito grande em mim, mas pela sinceridade da minha revolta que vem bem do Amor e não do Ódio, como podem supor. Cinco capítulos da minha Clara estão na gaveta; o livro há de sair... Penso, agora, dessa maneira; mas durante o resto do tempo em que estive no $O$ Globo, quase me conformei, tanto mais que o interesse que o diretor mostrou por mim não foi nada platônico (BARRETO, 1990, p. 136).

O romance contamina-se, então, de discurso autobiográfico, assim como o autobiográfico matiza-se de ficção. Esse processo relativiza os limites do ficcional e expõe os impasses da escrita, porque

[...] inserir alguma coisa (o discurso autobiográfico) noutra diferente (o discurso ficcional) significa relativizar o poder e os limites de ambas, e significa também admitir outras perspectivas de trabalho para o escritor e oferecer-lhe outras facetas do objeto literário, que se tornou diferenciado e híbrido (SANTIAGO, 2011, p. 17).

Há também referências ao leitor (“como podem supor”), sendo que a presença ou o desejo de interlocução fica mais evidente quando o narrador Isaías refere-se às práticas jornalísticas dos colegas. Para explicar a adaptação feita por Leporace, um dos poucos jornalistas que ainda lia, de um trecho do romance de Daudet ${ }^{1}$, Isaías convoca o leitor:

Os senhores lembram-se daquela passagem dos Reis no Exílio em que Colette de Rosen, cavalgando ao lado da rainha Frederica, atira-lhe indiretas referentes ao seu silêncio em face das infidelidades do marido? Lembram-se que a rainha, sentindo o golpe [...] Pois bem. Leporace não

\footnotetext{
${ }^{1}$ Os reis no exílio (Le rois em exile, 1878). Na Limana, nome dado por Lima Barreto à sua coleção de livros, aparece o registro da obra em francês. Note-se aí o cuidado do escritor para com o leitor de citá-la, no romance, em português.
}

\begin{tabular}{|l|l|l|l|l|}
\hline Pensares em Revista & São Gonçalo, RJ & n. 1 & 35-50 & jul.-dez. 2012 \\
\hline
\end{tabular}


teve dúvidas; agarrou a frase do diálogo e desenvolveu-a no seu estilo barroco, por quase uma coluna, do seguinte modo: [...] (BARRETO, 1990, p. 138).

O mundo de Isaías Caminha (a imprensa, a cidade, os intelectuais e suas ações de poder) já não é somente um dado objetivo, mas está contaminado de suas impressões e angústias. Por outro lado, esse mundo exterior deixa suas marcas na alma do protagonista.

O espaço de maior tensão e confronto para Isaías Caminha é o dos bastidores da imprensa, espaço ambicionado por um jovem intelectual. No romance, é um ambiente avesso à criatividade crítica, à produção intelectual, mas propício à manutenção das aparências de saber, à ostentação de poder e subserviência, por meio de manchetes sugestivas, achados anedóticos, leveza na paginação.

O protagonista contamina-se daquele ambiente, que também projeta suas teias sobre sua vontade, desejo e autonomia. Observa-se a vinculação, e coerência, com a primeira parte do romance, porque o autor não opta pelo cômico, pela distância e pela superioridade, mas, antes, escolhe a proximidade, que permite a crítica. A estratégia da sátira inclui a reflexão, feita pelo próprio Isaías, e, no romance, apresenta-se, além do ridículo, a consciência do ridículo. O mundo da imprensa, da política, do poder e do espetáculo não é somente representado como distorcido, mas também é analisado e comentado.

A proximidade do autor com o leitor e a quebra da distância crítica, o rompimento com a lei da causalidade e da escrita triunfante para narrar a trajetória do jovem protagonista, constituem interessantes estratégias. $\mathrm{O}$ romance realiza-se como crítica à perspectiva realista na concepção da narrativa, inserindo dúvidas e inquietações sobre o narrar, além do movimento não linear na exposição dos acontecimentos diversos, isto é, realizando uma montagem ou justaposição de tempos, espaços, estados de alma e situações.

Revela-se o caráter de ilusão da escrita como transparente e precisa, no registro das emoções e vicissitudes das experiências dos sujeitos; a escrita torna-se espaço de confrontação de diferentes paixões, emoções, interesses e pluralidades de "eus" que formam a subjetividade. Isso representa profunda crítica à ideia da essência lógica e racional da subjetividade e de uma escrita capaz de transcrevê-la.

As divisões, no texto, entre tempos e falas diversos (autor, narrador e personagem)

\begin{tabular}{|l|l|l|l|l|}
\hline Pensares em Revista & São Gonçalo, RJ & n. 1 & 35-50 & jul.-dez. 2012 \\
\hline
\end{tabular}


sugerem também uma coexistência nem sempre harmônica entre os diversos sentidos que constroem afetiva e culturalmente o "eu", num contexto social. Daí a escrita não poder ser o registro de recursos e estratégias de um sujeito que expõe, de forma estável e segura, seu processo de conhecimento e autoconhecimento, uma vez que a identidade, no romance, não é pensada como algo fixo e permanente. A escrita é o espaço de experiência desse sujeito, com uma relação tensa, múltipla, instável consigo mesmo e com o mundo.

O mal-estar de Isaías consiste na perda de paradigmas para o sujeito e da confiança na escrita para expressão do autoconhecimento; na incapacidade de perspectiva distanciada e crítica para narrar a si mesmo, suas dores e expectativas; na não garantia de ação eficaz e racional a partir da associação entre pensar e agir.

\section{A crise do romance}

O escritor utiliza referências importantes do romance do século XIX, como a trajetória de formação do jovem, sua busca de êxito e realização social; a experiência urbana, tema significativo também ao romance modernista; e a proposta de "memórias", frequente nos títulos de romances da literatura brasileira. No entanto, utiliza princípios formais que já introduzem nova realização estética do romance. Produz, portanto, uma crise, a qual não quer dizer insuficiência de forma, fracasso ou má qualidade estética.

A crise, em primeiro lugar, é característica própria do romance, cujos aspectos, como a plasticidade e a autocrítica, garantem, segundo Bakhtin (1988), a renovação do gênero. Em segundo lugar, compreende-se a crise como a consciência crítica acerca da impossibilidade de narrar, de escrever um romance, ou "as memórias", nas primeiras décadas do século XX e em seu contexto cultural efervescente, com os mesmos recursos estéticos e formais do século anterior.

A única maneira de continuar narrando seria contradizendo a forma da narrativa até então. Na forma antiga (ou a esperada pelo leitor), inserem-se os novos elementos formais, como a temporalidade complexa, uma subjetividade flutuante e instável, a crítica à concepção da linguagem límpida e transparente em relação ao real e a contaminação do ficcional pelo autobiográfico. Todos esses aspectos formais renovam o romance, no início do século XX, e alcançam os nossos dias.

\begin{tabular}{|l|l|l|l|l|}
\hline Pensares em Revista & São Gonçalo, RJ & n. 1 & 35-50 & jul.-dez. 2012 \\
\hline
\end{tabular}


Não há negação total do realismo no romance, negação esta que impossibilitaria seu grande objetivo e missão: tornar a literatura significativa para a reflexão e formação dos leitores. No entanto, há quebras constantes do pacto ficcional pela inserção direta da voz autoral, provocando uma identificação e reconhecimento por parte do leitor. Quebra-se um pouco a coerência da estrutura, isto é, a lei da causalidade na narrativa, não somente pelo fato de as explicações finais acerca da trajetória final do protagonista aparecerem no prefácio, mas também porque o encadeamento lógico, das motivações e ações, é rompido: Isaías termina o romance como começou: em deslocamento, insatisfeito, com seus sonhos intelectuais não realizados.

Há, também, um aprofundamento da perspectiva psicológica. Como vimos, a relativização da perspectiva temporal, por meio da justaposição de tempos distintos e do relato de tudo partir da consciência do protagonista, permite menor valorização da cronologia e dos acontecimentos externos. O mais importante é o resultado do tempo e das ações exteriores sobre a personalidade do sujeito. A corrosão da cronologia, da perspectiva temporal e do enredo está intimamente ligada à fluidez do sujeito, na imprecisão de seus contornos morais e na ausência de metas eficientes para alcançar seus objetivos. A crise anuncia, dessa maneira, nova forma de romance, nova concepção de subjetividade.

Recordações do escrivão Isaías Caminha convida-nos a acompanhar o relato das memórias de um intelectual, do interior à cidade, nas ruas, subúrbios e lugares onde o conhecimento torna-se espetáculo e poder, como os bastidores da imprensa. Ficamos tão envolvidos com as aventuras de Isaías que quase não observamos a profunda crítica à ideia de uma essência de subjetividade e de uma escrita capaz de transcrevê-la de modo transparente e sem obstáculos. Lima Barreto inova as marcas tradicionais do romance, questiona as referências conhecidas sobre subjetividade e, ainda, conta-nos uma boa história.

\section{Referências bibliográficas:}

AUERBACH, E. Na mansão de la Mole. In: Mimesis. 2. ed. São Paulo: Perspectiva, 1987, p. 405-441.

BAKHTIN, M. Questões de literatura e estética. São Paulo: Hucitec/Unesp, 1988.

\begin{tabular}{|l|l|l|l|l|}
\hline Pensares em Revista & São Gonçalo, RJ & n. 1 & 35-50 & jul.-dez. 2012 \\
\hline
\end{tabular}


BARRETO, A. H. L. Recordações do escrivão Isaías Caminha. São Paulo: Ática, 1990.

RANCIÈRE, J. O efeito de realidade e a política da ficção. Novos Estudos CEBRAP, São Paulo, n. 86, p. 75-90, mar. 2010.

SANTIAGO, S. Meditação sobre o ofício de criar. Gragoatá, Niterói, RJ, n. 31, p. 15-29, 2011.

Artigo recebido em: 31 de outubro de 2012 .

Artigo aprovado em: 15 de novembro de 2012.

\section{Sobre a autora:}

Mestra e Doutora em Teoria da Literatura pela Universidade Federal do Rio de Janeiro (UFRJ), com pesquisa sobre o escritor brasileiro Lima Barreto. Atualmente é Professora Associada de Teoria da Literatura da Universidade do Estado do Rio de Janeiro (UERJ). É autora de Lima Barreto e o sonho republicano (Tempo Brasileiro, 1995), Trincheiras de sonho: ficção e cultura em Lima Barreto (Tempo Brasileiro, 1998) e organizadora, junto com Antonio Houaiss, do volume Lima Barreto, da Coleção Archives / UNESCO (1997). Atua na área de Letras com ênfase em Teoria da Literatura e no Programa de Pós-Graduação em Letras da UERJ. 